\title{
Las regias y el rey de la cumbia (ficción crítica) ${ }^{1}$
}

\section{Rubí Carreño Bolívar}

Las regias cantan y bailan "no te metas con mi cucu, $\mathrm{cucu}^{\text {", }}$ un poco maníacamente (confesémoslo) totalmente solas en el medio de la pista. Son las divinas, las adivinas de la noche, si va a caer algo, o alguien, el amordelavida más que sea, que durará lo que un "chupa, chupa, chupa, pirulï", bajan cimbrándose hasta el piso mientras lamen un pico dulce imaginario. Las regias imitan a las cubanas que vieron la otra noche, esas que hacen tan bien el contoneo y la mímica que nadie se atrevería a sacarlas a bailar o a alguna otra parte sin pagar por su talento. Ellas, en cambio, son las damas gratis hasta las once-Oye, bonita- mira, hay que tener una estrategia que sea entre La Ley y el Orden y Mundo Animal, hay que inventar una, porque mira, hay casi puras minas. Acuérdate de que me llamo Gloria, soy parvularia y nada, nada de mis títulos y grados dice apreciando hacia atrás el impacto que su culi-currículo podría tener en la audiencia que empieza a llegar: "sandunguera, tú te vas por encima del nivel". A los tipos les gustan tontas, como tontas. Si son las mujeres las jerarcofílicas, dijo desapegada de su género y bailando casi feliz: "no tiene talento pero es buena moza, pero mira, mira, mira, lo que son las cosas".

El rímel, el cuero, el encaje les hace una coraza a estas chicas, con corralito sentimental a cuestas, crisis energética permanente, boquitas que alimentar, también solas en esa pista, cuatro trabajos ilustrados y un salario de damas gratis. José Donoso enfatizaría lo patético y putón de la escena. También las haría bastante más gordas y blandas, a fin de que el travesti saliera fortalecido y de que pareciera normal que el sexo con mujeres resulta algo asfixiante o anodino. Pero las regias eligen otro son, otra música para sacarse el peso y la desgracia. Si total, bailan, bastante bien, a veces hasta cantan, y total, como dice alguien por ahí no hay que ser Maradona para jugar al fútbol, ni cubana para comerse un pirulí. 
A propósito, ¿quién es ese canchero que cruza la pista, punteando a todos los de la barra como si estuviera en un permanente reguetton sin música? ¿De dónde sale ese perfume que dice a gritos que quiere algo más que "un meneíto pa quí un meneíto pa allá" esta noche? La Gloria no alcanza a decir nada más y lo tienen al frente, despliega una verba que lo delata como argentino (aunque todavía no habla de Borges ni de Lacan, tampoco de Boca y menos de los alfajores Jorgito, aunque seguro es cosa de darle tiempo). De lo que sí habla, y cómo habla, es de todas las palabritas que se dicen cuando los gatitos quieren leche, las estetiza, las convierte en una biblia del amor que hasta Neruda consultaría para dejar de escribir versos tristes y tirarse a la chascona muchas veces bajo un cielo que de verdad no le importaría si es o no es infinito.

¿Y tú eres argentino?, dijo la Gloria guardándose en buena parte el vos que usaba cuando se hacia la porteña con los peruanos y cubanos del delirio caribeño. No, yo soy el sexto hermano de los Jackson Five, ese que se salvo del padre. Cómo voy a ser argentino, si yo soy negro y trabajo. Alan Pauls, el artista de cine, ese es argentino, las trillizas de oro son argentinas, hasta la Pinina, grande o chica es argentina. Si allá la villa aparece en Aira y en Vega no más. Yo soy el curandero del amor, vengan para acá mis tickis, denme su manito, apuesto a que las dos se quieren mucho, ¿no? Son bien amigas ¿cierto?, dice juntándonos las manos en las suyas. Si es cosa de querer y decir no más, tal vez yo las podría ayudar, en algo.

La bonita le dice a la Gloria en el oído que sabe de él, que con la mezcla de negro y argentino se ha cogido a tres cuartas partes del Delirio; que es peligroso: que mi cucu, que mi ticky y terminas recomendándoselo a tus amigas; que hace el mismo juego que ellas, o sea turismo sexual en el propio barrio, sin ser gringas y gratis después de todas las crisis que han tenido los vecinos; que no se compra el cuento del cuerpo doliente del inmigrante y que colabora gentilmente en el goce de todo lo que se le cruce por delante o por detrás, no discrimina.

La bonita le dice que es una especie de Casanova del pueblo, una especie de don Juan sin el don, o más bien con el puro don de su aristocracia verbal, que es un Sade sin sadismo, y del lado económico de los borreguitos.-Ah, $\mathrm{O}$ sea que sea negro y que trabaje en el supermercado, lo salva de ser un hijo de puta, ¿no?, ¿eso me 
estás diciendo? Le dice la Gloria en la oreja, pero ya viene el rey de la cumbia con sus zapatos en punta que se había desaparecido detrás de unas cervezas con las que mojar la conversación. Pero las regias lo dejan con la pija y la cerveza expectantes y cual narratrices pero con los patrones ausentes comienzan a reflexionar. -Es un poco más complejo. O sea nosotras no hacemos turismo sexual, ¿ya? Jugamos con estereotipos y necesidades y no andamos diciendo más que en broma que queremos aprender de nuestros compañeros inmigrantes, conocer algo más de la cultura tropicana. El rey de la cumbia interviene, "el que imponga una moral a un mundo de mentiras es un reverendo pelotudo, o en su defecto un reverento hijo de puta, un falso profeta un impostor de morondonga, un hipócrita envilecido, por dos hojas [...] que la revolución posible es la de la cumbia y la de levantarse a una buena perra paraguaya", y que si las semitickis quisieran, él podría hacer una excepción con las dos semicorderillas de la clase media.

La Gloria quedó un $60 \%$ y un $43 \%$ por ciento casicogida (su doctorado no era en matemáticas), le pregunta que cómo es eso de la revolución cumbianchera, que la sola idea la deja en realidad, un 70\% casicogida, que de eso ella entiende que cuando todo falla, se cae a pedazos sin ninguna sombra que ampare o que proteja -ni siquiera la peregrina idea de ser los europeos en el exilio o los ingleses de América-, lo único que queda en pie, es el chacuchacucurucuchacucha de un goce que ni siquiera se encarga de tapar los olores proscritos o las malas palabras ( justo sonaba Calle 13). Como argentina aspiracional diría que sólo queda en pie la pulsión de vida y desde ese lugar no hay duda alguna entre coger y no coger, escribir o no escribir, ser o no ser. El rey de la cumbia quedó como en un 30\% casicogido por el discurso de la Gloria y se iba a poner a versear y a atolondrar lo dicho como era su costumbre. De puro curandero podía rescatar a Beatriz Viterbo de ser una reproductora de tesis de doctorado y convertirla en una paraguayita-boliviana-argentina. De puro curandero era capaz de inventar la artesanía librera de la era postindustrial, convertir el Aleph en un conventillo, no por reírse de Borges, cosa que también hizo Capusotto con el Bom Bom asesino, sino que para democratizarlo, encarnarlo en una argentina que está siendo. Pero la bonita lo interrumpió, y le dijo que ella le creía $100 \%$ su revolución (sobre todo al verse rodeada de mozos 
y bailarinas cubanas), que le creía, que ella sabía que había más opciones que el supermercado chileno, el Super Eltit, donde todos trabajabamos o que la bailanta cafiola argentina cucurtiana, que a lo mejor había más posibilidades que ser mano de obra o piernas abiertas, que tal vez, se podían subvertir los estereotipos, darlos vuelta. Pero el rey de la cumbia no la escucho, porque miraba a un tipo que bailaba en el segundo piso con un patirucito que le decía: Pedro, pa la próxima escríbete una donde las locas no sean tan duras y se salven pues, cómo es eso de que el fuego las quemaba y las locas seguían bailando, pero Pedro se reía, y seguía bailando. El rey de la cumbia que no cantaba no creía en eso de que todo el mundo arriba, y arriba las palmas, sabía que las más de las veces era abajo y abajo, los pobres del mundo y estaba medio aburrido con las semitiquis que para peor eran chilenas, esclavas de Obama, así que rápido y con cortesía, dejó a las regias, en sus especulaciones, de puro rey, amoroso y curandero les dejó algo mejor que una rosa amarilla vista al anochecer, o que un yogurt de marca Parra, algo mucho mejor que un tango del polaco, y eso es bien difícil, la vida no es una herida tan absurda, el rey dejo olor a Axe y ganas de ponerle una semilla a la matraca pa que suene, chacuchacurucuchacucha.

Notas

1 Ficción crítica en torno a El rey de la cumbia contra los fucking Estados Unidos de América. Santiago: Cuarto Propio, 2010. Leído en Antología en Movimiento: conversando con Washington Cucurto en La Chascona. Noviembre, 2010 . 